\title{
A method of assessment of sustainability of social and labor relations of a city-forming enterprise and a single-industry town
}

\author{
Irina Roshina ${ }^{1, \mathrm{a}}$, Natalya Artyukhova, \\ ${ }^{1}$ Tomsk State University, 634050 Lenin Avenue, 36, Tomsk, Russia
}

\begin{abstract}
In this article we consider one of the tools for managing a single-industry town - a method of assessment of its social and labor relations sustainability. We describe a mathematical model of calculating the integrated index and give instant assessment examples.
\end{abstract}

\section{Introduction}

Social and labor relations of city-forming enterprises and single-industry towns have special significance for regional economies, which is predefined by their specific nature and high vulnerability in the face of economic crises [1].

According to the results of the national government's monitoring [2], the total population of single-industry towns, as of 01.07 .2015 , comprises 13,6 million people, or $9,3 \%$ of the whole population of Russia. About 16,6 $\%$ of the working population are employed at cityforming enterprises.

In 179 single-industry towns, the level of unemployment surpassed the average national level $(1,9$ $\%$ of the workforce), moreover, in 70 single-industry towns the indicator is twice as high as the average.

According to the national Ministry of Economic Development as of the end of the first quarter of 2015, the most unfavorable situation (production decline due to decreasing consumer and investment demand) persists in the sector of heavy machinery production, transportation, wood production, as well as in iron and steel production and non-ferrous metallurgy.

Sustainable development of such relations is gaining importance due to the wide spread occurrence of singleindustry towns on the territory of the Russian Federation. Besides, social and labor relations of city-forming enterprises are the basis of social and economic sustainability of a single-industry town and the welfare of local population $[3,4]$.

\section{Theoretical framework}

In order to efficiently manage the process of sustainable development of social and labor relations, it, first, should be measured. Analysis of the extant literature shows that

\footnotetext{
${ }^{\mathrm{a}}$ Corresponding author: riv58@narod.ru

${ }^{\mathrm{b}}$ Corresponding author: artyuhova.na@mail.ru
}

the issue is highly understudied, namely there are no methods for comprehensive assessment of social and labor relations and their sustainability in single-industry environment, as they do not take into account the specifics of single-industry conditions and the influence of the city-forming enterprise. [5,6,7,8,9]. For this purpose we developed a method for assessing the social and labor relations sustainability of a city-forming enterprise and a single industry town (Method) comprised of four parts:

1) a methodological part, containing the information on data collecting, forecasting and calculating methods;

2) an analytical part, implying instant and full assessment of the sustainability level [10];

3) a forecasting part, suggesting an ability to forecast the indicator in terms of local specifics [11];

4) purpose-oriented analysis, which refers to testing strategic documents correspondence of city-forming enterprises and single-industry towns to the criteria of sustainability of social and labor relations (figure 1).

The instant assessment method allows evaluating the level of social and labor relations sustainability of a cityforming enterprise and a single-industry town. The goal of instant assessment is to define the problematic areas using the key indicators.

The examples of indicators used in instant assessment are given in Table 1. 


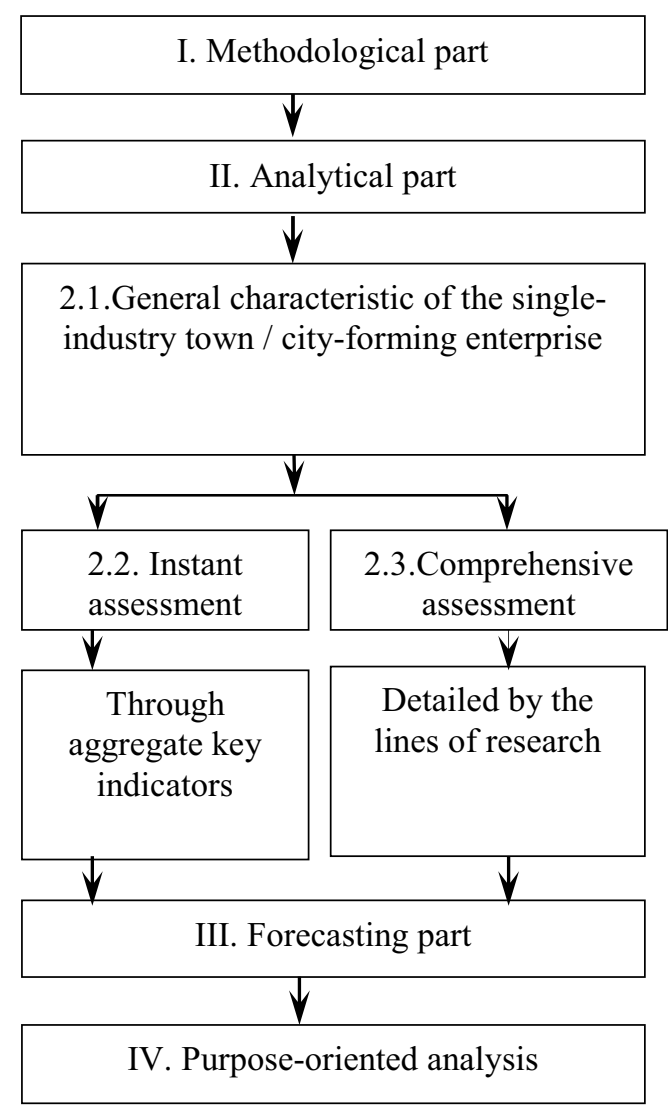

Fig. 1. The method structure

Table 1. Indicators of instant assessment

\begin{tabular}{|c|c|c|c|c|}
\hline \multirow{2}{*}{$\begin{array}{l}\text { Sub- } \\
\text { section }\end{array}$} & \multirow{2}{*}{$\begin{array}{l}\text { Indica- } \\
\text { tor }\end{array}$} & \multirow{2}{*}{$\begin{array}{l}\text { Calculations and } \\
\text { characteristic }\end{array}$} & \multicolumn{2}{|c|}{ Threshold } \\
\hline & & & $\max$ & $\min$ \\
\hline \multicolumn{5}{|c|}{$\begin{array}{l}\text { Section 1. Social and labor relations of city-forming } \\
\text { enterprises }\end{array}$} \\
\hline 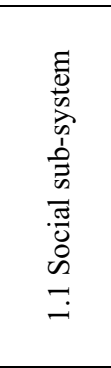 & 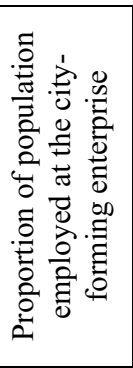 & $\begin{array}{l}\text { Population } \\
\text { employed at the } \\
\text { city-forming } \\
\text { enterprise divided } \\
\text { by the total } \\
\text { employment of the } \\
\text { single-industry } \\
\text { town. Characterizes } \\
\text { local employment } \\
\text { diversification. }\end{array}$ & 1 & 0 \\
\hline 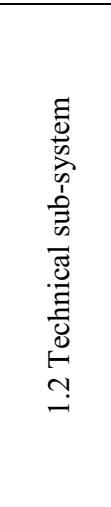 & 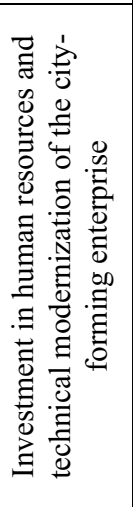 & $\begin{array}{l}\text { Investment in } \\
\text { human resources } \\
\text { and technical } \\
\text { modernization } \\
\text { divided by total } \\
\text { investment in the } \\
\text { single-industry } \\
\text { town. } \\
\text { Characterizes the } \\
\text { single-industry } \\
\text { town's investment } \\
\text { dependence on the } \\
\text { city-forming } \\
\text { enterprise }\end{array}$ & 2 & 0 \\
\hline
\end{tabular}

\begin{tabular}{|c|c|c|c|c|}
\hline 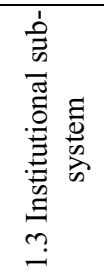 & 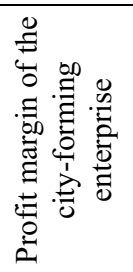 & $\begin{array}{l}\text { Net profit of the } \\
\text { city-forming } \\
\text { enterprise divided } \\
\text { by its revenues }\end{array}$ & 1 & 0,4 \\
\hline \multicolumn{5}{|c|}{$\begin{array}{l}\text { Section 2. Social and labor relations of a single-industry } \\
\text { town }\end{array}$} \\
\hline 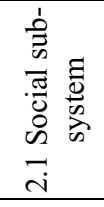 & 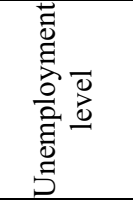 & $\begin{array}{l}\text { The number of } \\
\text { unemployed divided } \\
\text { by the total number } \\
\text { of employed and } \\
\text { unemployed }\end{array}$ & 1 & 0 \\
\hline 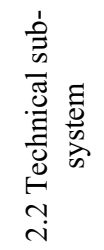 & 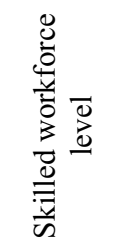 & $\begin{array}{c}\text { Number of skilled } \\
\text { workers divided by } \\
\text { total work force of } \\
\text { the single-industry } \\
\text { town }\end{array}$ & 1 & 0,15 \\
\hline 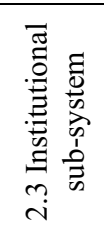 & 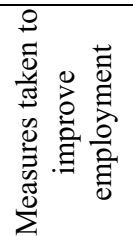 & $\begin{array}{l}\text { Real divided by } \\
\text { planned expenses of } \\
\text { the local budget on } \\
\text { employment } \\
\text { stimulation } \\
\text { expenses }\end{array}$ & 2 & 0 \\
\hline \multicolumn{5}{|c|}{$\begin{array}{l}\text { Section 3. Sustainability level of social and labor relations } \\
\text { in total }\end{array}$} \\
\hline 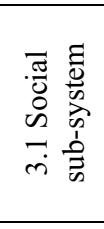 & 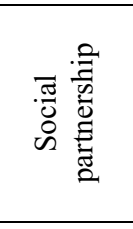 & $\begin{array}{l}\text { Number of workers } \\
\text { in the social } \\
\text { partnerships divided } \\
\text { by total employed } \\
\text { population of the } \\
\text { single-industry town }\end{array}$ & 1 & 0 \\
\hline 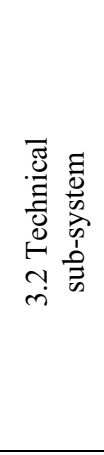 & 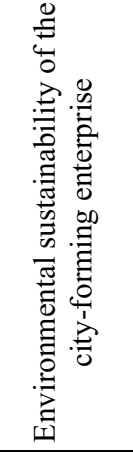 & $\begin{array}{l}\text { City-forming } \\
\text { enterprise's } \\
\text { expenses on } \\
\text { environmental } \\
\text { protection divided } \\
\text { by total investment } \\
\text { in the single- } \\
\text { industry town }\end{array}$ & $x$ & $x$ \\
\hline 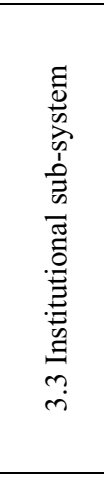 & 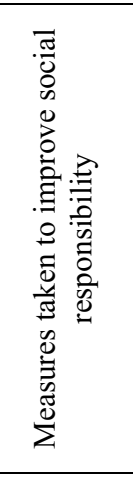 & $\begin{array}{c}\text { The indicator } \\
\text { characterizes local } \\
\text { government's } \\
\text { influence on social } \\
\text { responsibility } \\
\text { improvement. } \\
\text { Real divided by the } \\
\text { level of budgetary } \\
\text { expenses on } \\
\text { boosting civil } \\
\text { institutions and } \\
\text { responsible } \\
\text { entrepreneurship } \\
\end{array}$ & 2 & 0 \\
\hline
\end{tabular}

Comprehensive assessment implies a detailed evaluation of the problematic areas of social and labor relations, considering the specifics of single-industry towns and city-forming enterprises. 
Thus, the analytical part applies the constructor principle, which, in the course of assessment, provides for a complex situation-adjusted method, comprising multiple parts with various indicators. Therefore, the method is flexible and can be adjusted for every cityforming enterprise, thus facilitating pin-point detection of problems and trends in the social and labor sphere. This property of the method makes it fast and highly efficient.

An advantage of the method is the possibility to analyze the dynamics of sustainability both in general and in particular. This is a very important property as the situation, which is defined as favorable in one part in comparison to another, may alter the general picture or even distort it, whereas in the problematic areas, all subsystems need to be examined. Such pin-point analysis and timely reaction allow deciding certain escalated issues and defining what strategic lines of socioeconomic policy need to be adjusted.

\section{A mathematical model of the proposed method}

We use both quantitative and qualitative indicators. As they are not equally quantifiable, we used the standardization technique. The sustainability level then is measured in three steps.

Step 1. Calculation of coefficients:

a) for quantitative indicators we use the method of multidimensional comparative analysis based on threshold minimum and maximum values:

- a coefficient formula for the indicator correlates directly with sustainability level (1) (i.e. the higher the indicator, the higher the level of sustainability):

$$
k_{i}=\frac{x i-\min (x i)}{\max (x i)-\min (x i)},
$$

- a coefficient formula for the indicator correlates inversely with sustainability level (2) (i.e. the higher the indicator, the lower the level of sustainability):

$$
k_{i}=\frac{\max (x i)-x i}{\max (x i)-\min (x i)},
$$

where

$k_{i}$ is a coefficient measuring the level of social and labor relations' development by each value of the indicator (xi), hereafter referred to as a coefficient;

$\max (x i), \min (x i)$ are threshold values of the indicator.

Threshold values of each indicator are derived from statistical data and research databases.

b) for qualitative indicators we use the scoring method and expert evaluation.

Expert evaluation is conducted by means of interviewing at least 10 experts. Indicators are evaluated using an interval scale corresponding to a value range of the sustainability indicator of 0 to $1: k_{i} \leq 0,3-$ low sustainability; $0,3<k_{i} \leq 0,6$ - medium sustainability; 0,6 $<k_{i}<1-$ high sustainability.
To assess the interview results, we find a coefficient calculated as arithmetic mean of expert scores (3).

$$
k_{i=} \sum \frac{s_{j}}{n}
$$

where

$k_{i}$ is arithmetic mean of expert scores of index $\mathrm{i}$;

$S_{j}$ is scores obtained from expert $\mathrm{j}$;

$n$ is a number of experts.

Step 2. Calculation of integrated indices for each section. It is presented as geometric mean of coefficients obtained from each part (4):

$$
I_{n}=\sqrt{ } S_{S} K_{j},
$$

where

$K_{j}$ stands for the index of social and labor relations sustainability for sub-section $\mathrm{j}$ : a social, technical and institutional subsystem;

$I_{n} \quad$ is the index of social and labor relations sustainability for section $\mathrm{n}$.

Step 3. Calculation of integrated index (SII) of social and labor relations sustainability (5):

$$
I_{S I I}=\sqrt[3]{I_{1} \times I_{2} \times I_{3}}
$$

where

$I_{S I I}$ stands for the integrated index of social and labor relations sustainability;

$I_{1}$ is the index of social and labor relations sustainability for section 1 "Social and labor relations of city-forming enterprises";

$I_{2}$ is the index of social and labor relations sustainability for section 2 "Social and labor relations of a single-industry town";

$I_{3}$ is the index of social and labor relations sustainability for section 3 "Sustainability level of the social and labor relations in total".

So the result of the analytical part will be calculation of the integrated index of social and labor relations sustainability in single industry environment (high, medium and low) in the range of $0-1$. This index reflects the level of economy and labor market diversification, social and economic stability risks, advancement of social partnership and responsibility.

If $I_{S I I} \geq 0,6$, it means a high level of social and labor relations sustainability. All analyzed indicators show satisfactory values having small possible deviations from the benchmark; management of social and labor relations is efficient; the dependence on a city-forming enterprise is decreasing; labor market of the single-industry town demonstrates a growth pattern.

If $0,6>I_{S I I} \geq 0,3$, it means a medium level of sustainability. There are certain threats to sustainable development; a negative tendency is traced in indicators and problematic zones in a number of sub-sections; reforms in problematic areas are required.

If $I_{S I I}<0,3$, it means a low level of sustainability. There are negative tendencies and complications in most areas of social and labor relations; management is inefficient; main strategic directions of social and labor 
relations of a city-forming enterprise and a singleindustry town should be reevaluated.

We suggest applying the method to assess social and labor relations sustainability of a city-forming enterprise and a single-industry town to detect problematic areas and negative trends on a quarterly basis.

\section{Conclusions}

General positive outcomes of the proposed methodology are as follows:

- it takes into account specifics of social and labor relations in city-forming enterprises and single-industry towns;

- it assesses the social and labor relations from the perspective of sustainability;

- it combines micro- and meso-level applied methods;

- it implies both instant and full assessment of problematic areas, as well as forecasting;

- it has applicable software for quick and easy calculation (software patent No 2014661200 of 24.10.2014).

In general the method allows assessing the efficiency of various measures taken by the management of the city-enterprise and local government, it also focuses on the quality and standard of life, labor market and employment diversification, working conditions and safety, social partnership and responsibility etc. Mismatched goals of sustainable development, social and labor policies can lead to escalation of problems in the social sphere. Thus the method helps to define the negative tendencies.

In view of these findings, the method presented can be used by government as an effective tool for monitoring, assessment and management of social and labor relations sustainability in single-industry environments.

\section{References}

1. I.V. Roshina, N.A. Dyatlova, Tomsk State University Journal, 273, 158-162 (2013)

2. On monitoring socio-economic situations of the cities (2015) Retrieved from http://government.ru/orders/19717/

3. I.V. Roshina, N.A. Dyatlova, G.S. Roshina, Tomsk State University Journal. Economic Section, 4 (20), 54-63 (2012)

4. I.V. Roshina, N.A. Dyatlova, Izvestiya of Altai State University. Section: pedagogy, psychology, law, philology, arts, philosophy, sociology, and economics, 2/2 (78), 278-283 (2013)

5. S.N. Bobylev, O.V. Kudryavtsev, S.V. Solovyeva, Regional economics, 3, 101-110 (2014).

6. O.V. Veredyuk, Vestnik of Saint-Petersburg University, 1, 25-32 (2013)

7. G. Yu. Vetrov, D.V. Vizgalov, A.A. Shanin, N. I. Shevyrova, Socio-economic indicators of municipalities. (Moscow: Urban Economics Institute fund, 2002)
8. V.S. Rakovskaya, O.S. Usmanova, Russian Entrepreneurship, 2 (194), 48-52 (2011)

9. T.V. Uskova, L.G. Iogman, S.N. Tkachuk, A.N. Nesterov, N.Y. Litvinova, Single-industry town: the management. Vologda: ISEDT RAS, 55-75 (2012)

10. I.V. Roshina, N.A. Dyatlova, Tomsk State University Journal. Economic section, 4 (24), 73-78 (2013)

11. I.V. Roshina, N.A. Dyatlova, Vestnik of Kuzbass State Technical University, 6 (100), 143-149 (2013) 